\title{
PENGEMBANGAN MEDIA PEMBELAJARAN BERBASIS APLIKASI I-SPRING UNTUK PENINGKATAN KUALITAS TEACHING METHOD BAGI GURU SMK DI BALIKPAPAN
}

\section{DEVELOPMENT OF LEARNING MEDIA BASED ON I-SPRING APPLICATION FOR QUALITY IMPROVEMENT OF TEACHING METHOD FOR VOCATIONAL HIGH SCHOOL TEACHERS IN BALIKPAPAN}

\author{
Andi Sri Irtawaty*, Maria Ulfah, Hadiyanto, Suhaedi \\ Jurusan Teknik Elektro, Poltekba, Balikpapan \\ Email : andi.sri@poltekba.ac.id; maria.ulfah@poltekba.ac.id; hadiyanto@ poltekba.ac.id; \\ suhaedi@poltekba.ac.id
}

\begin{abstract}
ABSTRAK
Media pembelajaran interaktif berbasis I-Spring merupakan media pembelajaran yang mengkombinasikan audio, video dan quiz maker yang terintegrasi menjadi satu kesatuan, sehingga memberikan kemudahan bagi tenaga pendidik dalam mentransfer materi bahan ajar kepada peserta didiknya melalui infrastruktur program aplikasi dan pemanfaatan media elektronik sebagai bagian dari metode edukasinya. Oleh karena itu, kegiatan pengabdian kepada masyarakat berupa pelatihan pengembangan media pembelajaran berbasis aplikasi ispring ditujukan untuk peningkatan kualitas teaching method pada guru SMK di Balikpapan. Peserta pelatihan sekaligus mitra dalam kegiatan ini adalah para guru dan siswa SMK Pangeran Antasari di kota Balikpapan, berjumlah 15 orang guru dari berbagai bidang studi dan 5 orang siswa perwakilan dari kelas X (Sepuluh). Masih minimnnya pengetahuan guru terkait teknologi komputer, maka tim penyelenggara dari Jurusan Teknik Elektronika Politeknik Negeri Balikpapan memberikan metode pelatihan dengan cara penyampaian materi, praktek langsung dan demonstrasi menyajikan hasil karya dari masing-masing peserta. Hasil evaluasi berdasarkan pengisian kuisioner dan pengamatan langsung, menunjukkan bahwa kegiatan ini berhasil 100\% karena peserta pelatihan mampu mengimplementasikan aplikasi I-Spring dalam membuat media pembelajaran multimedia yang dilengkapi soal kuis, meskipun hanya $85 \%$ peserta pelatihan yang mampu menganalisa dan mengembangkan secara kreatif materi pelatihan yang diberikan.
\end{abstract}

Kata Kunci:Aplikasi I-Spring, Media Elektronik, Audio, Video.

\begin{abstract}
I-Spring-based interactive learning media is a learning media that combines audio, video and quiz maker that are integrated into one unit, thus providing facilities for educators to transfer teaching materials to their students through the application program infrastructure and the use of electronic media as part of the method education. Therefore, community service activities in the form of training in developing instructional media based on I-spring applications are aimed at improving the quality of teaching methods for vocational teachers in Balikpapan. The training participants as well as partners in this activity were teachers and students of Pangeran Antasari Vocational School in the city of Balikpapan, totaling 15 teachers from various fields of study and 5 students representing class $X$ (Ten). The lack of knowledge of teachers regarding computer technology, the organizing team from the Department of Electronics Engineering, Balikpapan State Polytechnic provided training methods by delivering material, direct practice and demonstration to present the work of each participant. Evaluation results based on filling out questionnaires and direct
\end{abstract}


observation, showed that this activity was $100 \%$ successful because the trainees were able to implement the I-Spring application in making multimedia learning media equipped with quiz questions, even though only $85 \%$ of the participants were able to analyze and develop creatively the training material which are given.

Keywords: I-Spring Application, Electronic Media, Audio, Video.

\section{PENDAHULUAN}

\section{Analisa Situasi}

Seiring perkembangan informasi teknologi dan komputer, salah satu faktor yang mempengaruhi kualitas pendidikan adalah penyajian materi pembelajaran yang kreatif dan inovatif. Terkait dengan hal tersebut, maka perlu adanya media pembelajaran yang dapat menarik minat belajar siswa, sehingga suasana pembelajaran lebih nyaman dan menyenangkan. Aplikasi I-Spring adalah solusinya. Aplikasi tersebut menyediakan fitur-fitur yang dapat mengembangkan materi bahan ajar dalam format power point menjadi materi multimedia dengan format html yang dapat dilengkapi audio (music atau suara penyaji), video (tutorial contoh-contoh penjelasan materi) dan quiz maker (soal-soal latihan secara online).

Dalam peningkatan kualitas pendidikan, dibutuhkan sumber daya manusia yang memiliki kompetensi di bidang IT yang cukup. Oleh karena itu, kegiatan Pengabdian kepada Masyarakat yang dilaksanakan oleh Politeknik Negeri Balikpapan berupa pelatihan pengembangan media pembelajaran multimedia berbasis aplikasi I-spring untuk peningkatan kualitas teaching method pada guru SMK di Balikpapan.

Sasaran mitra kegiatan pengabdian masyarakat dengan Program Penerapan Ipteks ini adalah para guru dan siswa SMK Pangeran Antasari yang berada di tengah pusat kota Balikpapan. Pemilihan mitra Program Kemitraan Masyarakat (PKM) tersebut didasarkan pada lokasi yang berdekatan, yaitu terletak di Jalan Mekar Sari No.1 RT.30 Balikpapan Tengah Kota Balikpapan, Kalimantan Timur. SMK Pangeran Antasari merupakan salah satu sekolah swasta favorit di kota Balikpapan yang kompetensinya di bidang keahlian teknik. Para guru dan siswa sebaiknya memiliki keahlian dasar di bidang teknologi komputer, mengingat perkembangan informasi yang semakin pesat, tentunya wajib diimbangi dengan pengetahuan dan keterampilan sumber daya manusia yang kompeten di bidang tersebut.

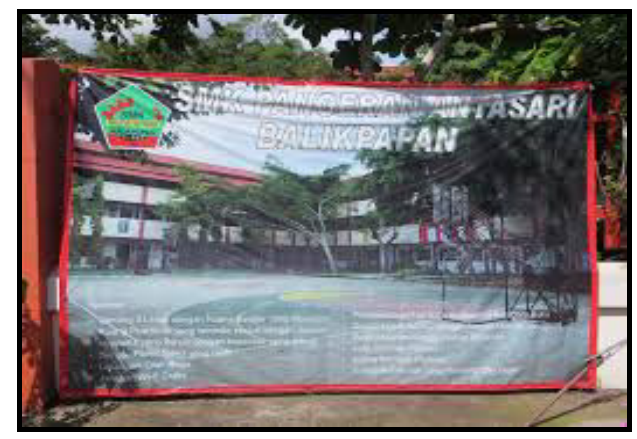

Gambar 1. Gedung SMK Pangeran Antasari

Salah satu harapan utama Politeknik Negeri Balikpapan sebagai pihak penyelenggara adalah tujuan akhir dari 
kegiatan pelatihan tersebut tercapai, yaitu para guru dan siswa dapat membuat media pembelajaran multimedia dengan berbasis aplikasi I-Spring sesuai disiplin ilmu masingmasing guru dan siswa, sehingga suasana pembelajaran di kelas menjadi lebih nyaman, kondusif dan menyenangkan.

\section{Permasalahan Mitra}

Berdasarkan latar belakang yang telah diuraikan, maka permasalahan yang timbul pada mitra adalah sebagai berikut :

1. Bagaimana melatih guru dan siswa SMK Pangeran Antasari dalam membuat media pembelajaran yang inovatif dan kreatif.

2. Bagaimana menjelaskan prosedur pengembangan media pembelajaran berbasis multimedia kepada guru dan siswa SMK Pangeran Antasari.

3. Bagaimana menerapkan software I-Spring dalam membantu para guru dan siswa SMK Pangeran Antasari dalam menyelesaikan permasalahan dalam pembuatan media pembelajaran berbasis multimedia sehingga dapat menarik minat belajar siswa.

4. Bagaimana melatih para guru dan siswa SMK Pangeran Antasari dalam membuat soal-soal ujian yang disajikan dalam bentuk quiz maker.

Oleh karena itu, solusi dan target luaran kegiatan pengabdian kepada masyarakat ini adalah sebagai berikut :

1. Guru dan siswa SMK dapat membuat media pembelajaran multimedia berbasis
I-Spring yang inovatif dan kreatif, sehingga dapat menarik minat belajar siswa dan menciptakan suasana pembelajaran di kelas lebih nyaman, kondusif dan menyenagkan.

2. Para guru SMK Pangeran Antasari dapat membuat soal-soal ujian secara online yang disajikan dalam bentuk quiz maker, sehingga memudahkan penilaian akhir terhadap bidang studi yang diajarkan.

\section{METODE PELAKSANAAN KEGIATAN}

Metode pelaksanaan kegiatan berupa pelatihan pengembangan media pembelajaran berbasis aplikasi I-Spring dalam peningkatan kualitas teaching method untuk guru-guru SMK di kota Balikpapan, dimana lokasi kegiatan bertempat di SMK Pangeran Antasari. Adapun tahapan atau langkahlangkah dalam pelaksanaan metode tersebut meliputi :

\section{Tahapan pertama}

Dalam tahap ini, tim penyelenggara melakukan survey lokasi dan studi kasus ke tempat mitra yaitu di SMK Pangeran Antasari.

2. Tahapan kedua

Selanjutnya tim penyelenggara melakukan persiapan-persiapan awal berupa pengajuan proposal yang ditujukan kepadamitra, membuat surat perjanjian kerjasama untuk melaksanakan kegiatan pengabdian kepada masyarakat, dan pengajuan proposal internal antara Jurusan Teknik Elektronika dan P3M. 


\section{Tahapan ketiga}

Pada tahap ini, tim penyelenggara melakukan persiapan inti berupa dan menyiapkan software aplikasi I-Spring.

4. Tahapan keempat

Merupakan tahapan pelaksanaan kegiatan pelatihan pengembangan media pembelajaran multimedia berbasisaplikasi I-Spring untuk meningkatkan kualitas Teaching Method bagi guru dan siswa SMK Pangeran Antasari. Diawali dengan penyajian materi dasar terkait aplikasi ISpring terutama terkait tentang cara mengoperasikan aplikasi I-Spring tersebut. Dilanjutkan proses penginstalan software bagi masing-masing peserta pelatihan dan pemberian praktek langsung.

5. Tahapan kelima

Dalam tahap ini, tim penyelenggara PkM melakukan analisa terhadap hasil pelatihan berupa pengamatan dan penilaian terhadap demonstrasi hasil karya para peserta pelatihan.

6. Tahapan keenam

Merupakan tahapan evaluasi dan kesimpulan hasil akhir dari kegiatan PkM. Parameter utama sebagai tolok ukur adalah hasil pengisian kuisioner dari seluruh peserta pelatihan dan hasil karya peserta berupa media pembelajaran multimedia berbasis I-Spring. pembuatan spanduk, menyiapkan perlengkapan ATK bagi peserta pelatihan, membuat materi presentase
Diagram alir / flowchart dari pelaksanaan

kegiatan PkM disajikan pada gambar 2.

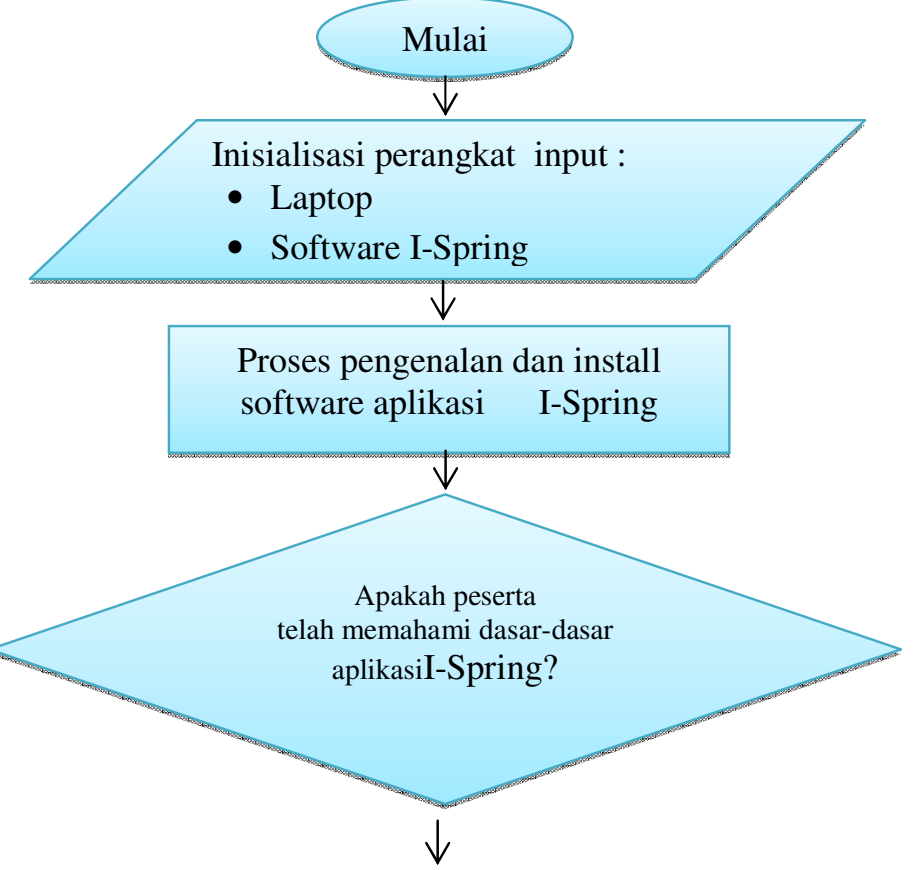

Proses pelatihan pembuatan media pembelajaran dengan aplikasi I-Spring

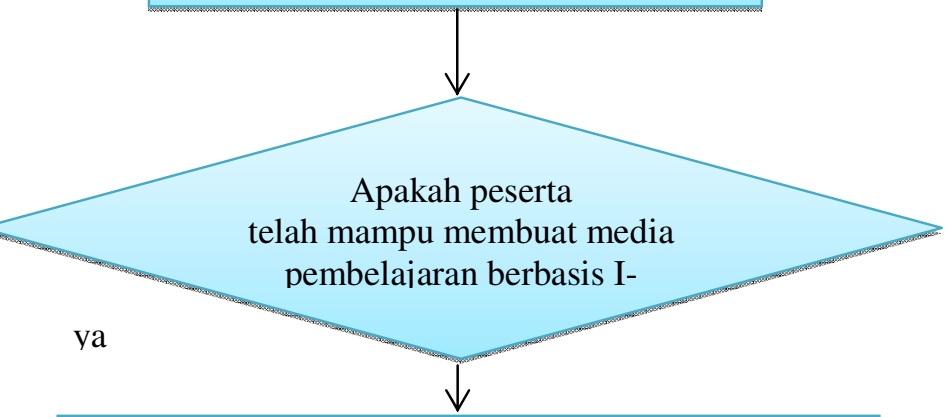

Produk akhir berupa media pembelajaran berbasis multimedia I-Spring

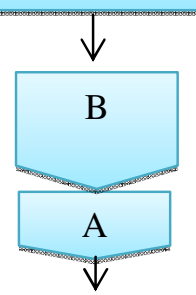

Pembuatan laporan akhir dan publikasi produk

Selesai

Gambar 2. Diagram alir / flowchart pelaksanaan kegiatan PkM 


\section{HASIL DAN PEMBAHASAN}

Pelaksanaan kegiatan PkM di SMK Pangeran Antasari berlangsung selama 2 hari dengan materi kegiatan seperti diperlihatkan pada tabel 1.

Tabel 1. Materi kegiatan PkM

\begin{tabular}{|l|l|l|}
\hline No & Tanggal & Materi kegiatan \\
\hline 1 & 10 & $\begin{array}{l}\text { a. Pengenalan dasar- } \\
\text { dasar aplikasi I-Spring }\end{array}$ \\
\cline { 3 - 3 } & $\begin{array}{l}\text { Agustus } \\
\text { b. Penginstalan software } \\
\text { aplikasi I-Spring }\end{array}$ \\
\cline { 3 - 4 } & $\begin{array}{l}\text { c.Peserta } \\
\text { mempraktekkan } \\
\text { langsung aplikasi I- } \\
\text { spring didampingi } \\
\text { oleh asisten } \\
\text { pendamping(mahasis } \\
\text { wa Poltekba) }\end{array}$ \\
\hline 2 & 11 & $\begin{array}{l}\text { Evaluasi dan } \\
\text { penilaian hasil karya } \\
\text { Agustus }\end{array}$ \\
\cline { 3 - 4 } & 2018 & $\begin{array}{l}\text { e. Peserta pelatihan. } \\
\text { dan kesimpulan }\end{array}$ \\
\hline
\end{tabular}

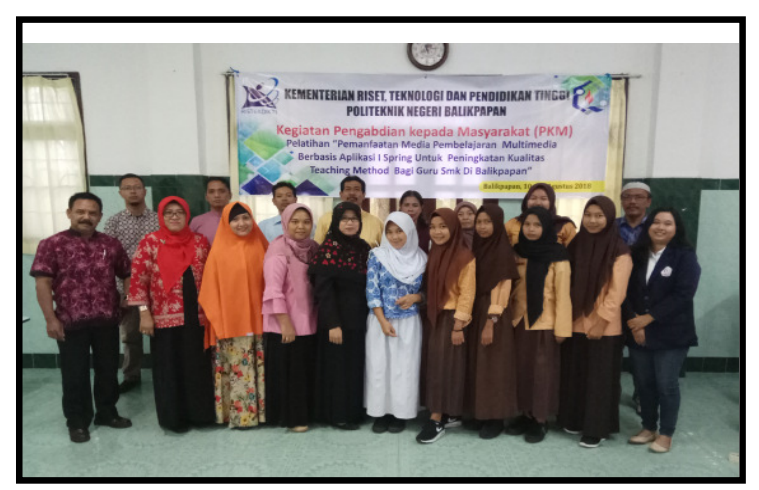

Gambar 3. Peserta pelatihan

Berdasarkan hasil pelaksanaan kegiatan $\mathrm{PkM}$, pengembangan media pembelajaran multimedia berbasis aplikasi I-spring untuk meningkatkan kualitas teaching method pada guru SMK di Balikpapan maka dibutuhkan kepakaran sebagai berikut :

1. Kemampuan dalam menginstalasi aplikasi I-Spring.
2. Kemampuan dalam menggunakan feature-feature aplikasi I-Spring.

3. Kemampuan dan merekam audio narasi materi bahan ajar berbasis aplikasi I-Spring.

4. Kemampuan dalam menyisipkan file video ke dalam aplikasi I-Spring.

5. Kemampuan dalam kolaborasi audio formatting dan video formatting.

6. Kemampuan dalam membuat quizmaker.

7. Kemampuan dalam mengkonversi dari format ppt ke format swf (flash) atau html.

Uraian selengkapnya dijelaskan sebagai berikut :

1. Kemampuan dalam menginstalasi aplikasi I-Spring.

Ada 2 file software yang disediakan yaitu:

Spring Suite 8.7.0 Build 21274 x64.kuyhA... iSpring Suite 8.7.0 Build 21274 x86.kuyhA...

Gambar 4. File rar software aplikasiI-Spring

Sebelum menginstalasi aplikasi I-Spring, maka perhatikan processor laptop peserta. Ada yang 32 bit dan ada yang 64 bit. Jika 32 bit, maka yang diinstal adalah i-spring suite 8.7.0 Build21274 x 86. Sedangkan jika 64 bit, maka yang diinstal adalah i-spring suite 8.7.0 Build 21274 x 64.

2. Kemampuan dalam menggunakan featurefeature aplikasi I-Spring.

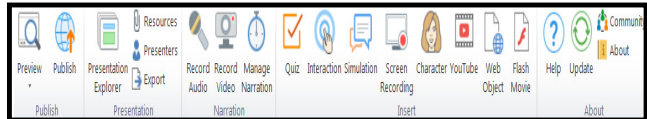

Gambar 5. Feature-feature aplikasi I-Spring Ada 6 feature utama yang akan senantiasa 
digunakan apabila membuat media pembelajaran multimedia berbasis aplikasi ispring, yaitu record audio, record video, manage narration, youtube, quiz dan publish.

3. Kemampuan dan merekam audio narasi materi bahan ajar berbasis aplikasi ISpring. Feature yang diklik adalah record audio, yaitu feature aplikasi i-spring yang berfungsi merekam narasi audio dengan cara membaca teks dengan keras atau narasi lainnya dan mensinkronisasi dengan slideshow. Jika record audio diklik, maka tampilannya seperti pada gambar 6 berikut :

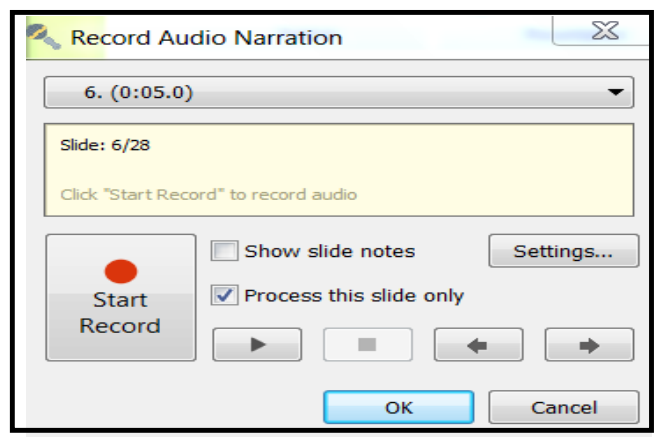

Gambar 6. Tampilan menu record audio Arah panah kiri dan kanan berfungsi untuk memilih slide yang akan ditambahkan audio narasi. Jika ingin menambahkan audio per slide, maka klik "process this slide only". Sedangkan jika ingin langsung menambahkan audio secara keseluruhan untuk seluruh slide, maka klik show slides notes. Disarankan untuk memilih "process this slide only", karena jika ingin mengedit salah satu slide secara random, lebih mudah dan hanya mengklik arah panah menuju slide yang akan direvisi. Untuk memulai proses merekam audio, klik start record, dan setelah selesai diakhiri dengan mengklik OK untuk menyimpan rekaman audio narasi yang ditambahkan pada materi presentase.

4. Kemampuan dalam menyisipkan file video ke dalam aplikasi I-Spring

Feature yang diklik adalah video record yaitu feature aplikasi i-spring yang berfungsi merekam narasi audio sekaligus menampilkan wajah yang membaca teks / narasi dari materi presentase yang akan dijadikan media pembelajaran multimedia berbasis I-spring menggunakan fasilitas webcame pada laptop, seperti yang disajikan pada gambar 7 .

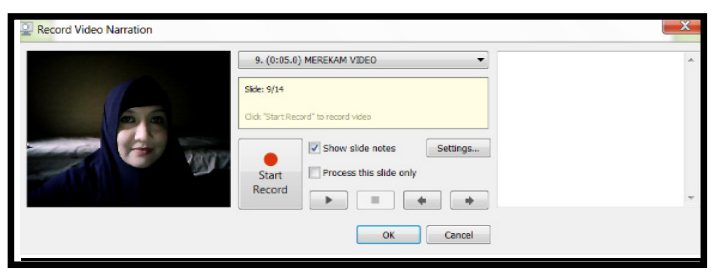

Gambar 7. Tampilan menu record video

Pada dasarnya tampilan menu pada record video sama dengan record audio. Perbedaannya hanya ada tambahan video webcame dari pengisi audio.

5. Kemampuan dalam kolaborasi audio formatting dan video formatting.

Feature yang diklik adalah Manage Narration, yaitu feature aplikasi i-spring yang mengkombinasikan audio dan video. Perhatikan gambar 8 berikut:

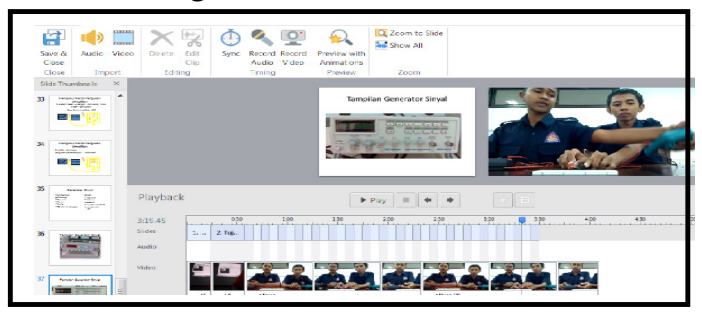

Gambar 8. Tampilan menu manage narration 
Manage narration adalah feature yang sangat kompleks. Selain menampilkan slide, pada menu ini dapat disisipkan video yang diletakkan berdampingan dengan slide. Selain itu, mudah diedit serta dapat divariasikan antara audio pembuat narasi dan music. Apabila ingin menghilangkan audio narasi yang sudah terekam, maka klik "edit klik", maka tampilannya seperti pada gambar 8.

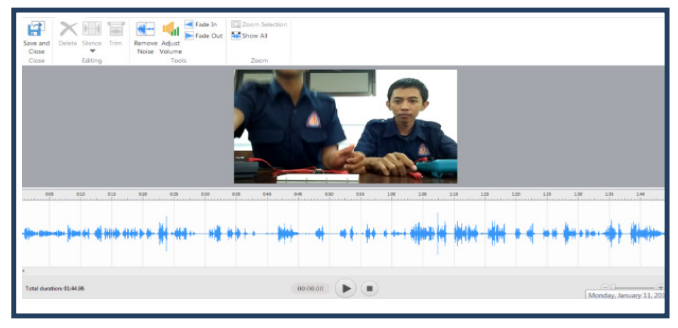

Gambar 9. Tampilan "edit klik"

Audio dapat diedit dengan klik "adjust volume" atau dihilangkan dengan klik "remove noise", lalu disave and close.

\section{Kemampuan dalam membuat quizmaker}

Feature yang diklik adalah quiz, maka tampilannya sebagai berikut :

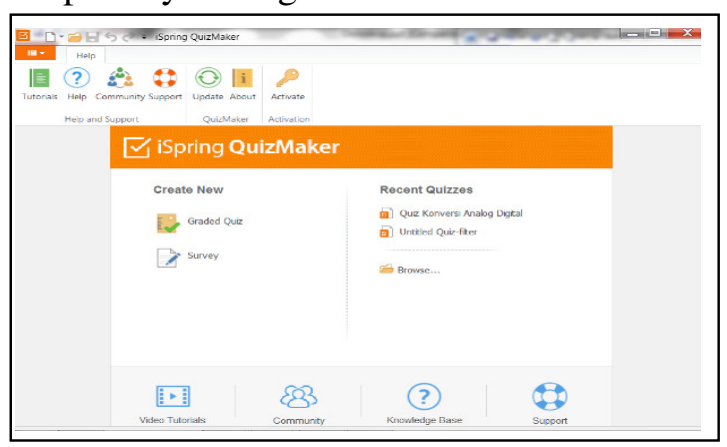

Gambar 10. Tampilan menu quizmaker

Selanjutnya klik graded quiz jika baru pertama kali akan membuat soal-soal latihan secara online.Untuk memilih tipe soal yang diinginkan, klik graded question. Ada 10 tipe soal yang dapat dipilih. Pada umumnya soal online menggunakan tipe multiple choice.

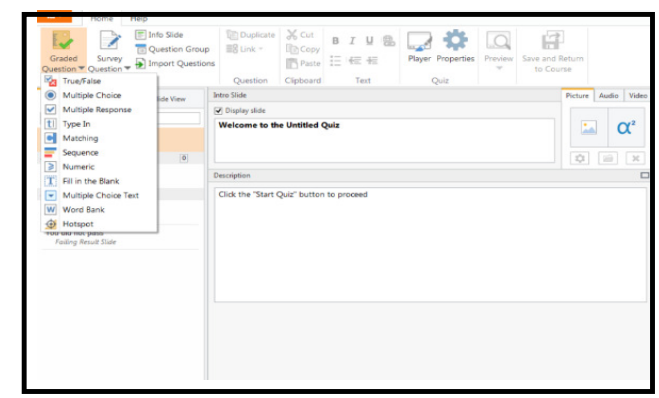

Gambar 11. Menu utama pada quizmaker

Pada sisi kanan soal, dapat ditambahkan picture, audio, video, bankan dapat disisipkan rumus matematika, dengan mengklik insert question. Jika jumlah soal telah mencukupi, maka klik "save and return to course".

Sebagai catatan bahwa quizmaker dapat disisipkan pada slide yang diinginkan. Umumnya diletakkan setelah uraian narasi tiap sub pokok bahasan materi pembelajaran.

7. Kemampuan dalam mengkonversi dari format ppt ke format swf (flash) atau html.

Langkah terakhir yang dilakukan adalah mengkonversi materi pembelajaran dari format ppt ke format swf (flash) atau html. Caranya dengan mengklik publish, dan tampilannya sebagai berikut :

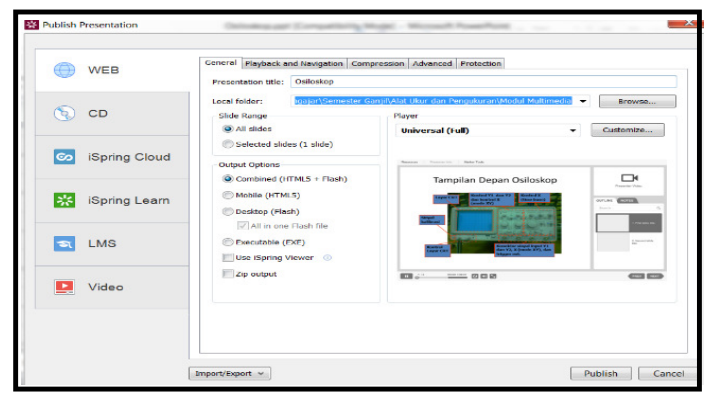

Gambar 12. Tampilan menu publish

Untuk menempatkan file pada drive tertentu, klik browse. Disarankan memilih combine (html+flash), agar file yang telah 
dikonversi dapat diakses secara online internal oleh siswa. Ada 6 option yang dapat dipilih, yaitu web, $\mathrm{CD}$, ispring cloud, ispring learn, LMS dan video. Setelah memilih salah satu option, klik publish, maka

media pembelajaran multimedia berbasis ispring telah selesai.

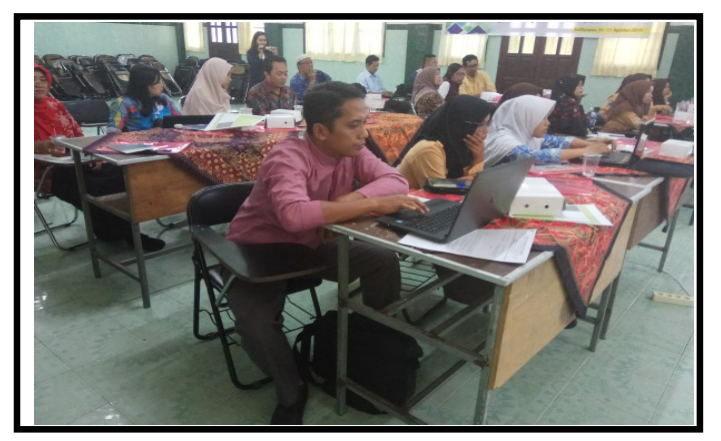

Gambar 13. Kegiatan pelaksanaan PkM

Berdasarkan evalusi dan penilaian tim penyelenggara terhadap peserta pelatihan (mitra), hampir $100 \%$ peserta dapat membuat media pembelajaran menggunakan aplikasi ispring. Hasil kuisioner peserta yang terekap dinyatakan bahwa dari 20 peserta pelatihan, sekitar $85 \%$ yang memiliki kompetensi di bidang IT, sehingga mampu mengimplementasikan aplikasi i-spring secara kreatif dan inovatif. Berarti kegiatan pelatihan PkM yang dilaksanakan dianggap berhasil.

\section{KESIMPULAN}

Berdasarkan hasil dan pembahasan, dapat ditarik kesimpulan sebagai berikut :

1. Aplikasi i-spring memberikan manfaat bagi para guru dan siswa dalam menyajikan materi presentase multimedia yang kreatif, inovatif dan menyenangkan karena dilengkapi dengan audio, video, dan soal-soal quiz yang terintegrasi menjadi satu kesatuan serta dapat disajikan secara online.

2. Dari 20 peserta pelatihan, sekitar sekitar 85\% yang memiliki kompetensi di bidang IT sehingga mampu mengimplementasikan aplikasi i-spring secara kreatif dan inovatif.

\section{SARAN}

1. Kegiatan $P k M$ yang dilaksanakan di SMK Pangeran Antasari mendapatkan respon positif dari seluruh peserta pelatihan (mitra). Saran dari mitra agar sekiranya kegiatan pelatihan tersebut dapat dilaksanakan kembali pada tahun berikutnya dengan inovasi yang lebih berkembang.

2. Sebaiknyapada kesempatan berikutnya, tim penyelenggara PkM akan mengadakan kegiatan pelatihan tersebut dengan mengundang guru-guru dari sekolah-sekolah lainnya.

\section{REFERENSI}

Hernawati.Kuswari, Modul Pelatihan I Spring, FMIPA UNY, Yogyakarta

Kuriawan.Yahya, Belajar Sendiri MS Power Point 2010, Jakarta , PT. Elex Media Komputindo

Munawwaroh.Madinatul, Pengembangan Media Pembelajaran IPA Berbasis Multimedia I-Spring Suite 6.2 Untuk SD/MI Kelas V,UIN Sunan Kalijaga Yogyakarta, 2014

P3M, Renstra Pengabdian Masyarakat, Politeknik Negeri Balikpapan,

Taufiq.Abd Rahman, Pengembangan Media Pembelajaran Sains Biologi ADOBE 
Flash untuk Siawa SMP/MTS Kelas UPT eLearning ITB, Merancang Bahan Ajar VII. Fakultas Sains dan Teknologi UNIN Sunan Kalijaga.2013 